\title{
ANALISIS KESULITAN GURU DALAM MENGEMBANGKAN INDIKATOR PEMBELAJARAN KURIUKULM 2013 SDN 210 BOTTOPENNO
}

\author{
Ryaas Rasyid ${ }^{1}$,Muhammad Amran ${ }^{2}$, Satriani $^{3}$, Rosdiah ${ }^{4}$ \\ ${ }^{1}$ Universitas Negeri Makasar \\ Email: ryaastasyid2@gmail.com \\ 2 Universitas Negeri Makasar \\ Email: neysaamran@yahoo.co.id \\ ${ }^{3}$ Universitas Negeri Makasar \\ Email: Satriani.dh@gmail.com \\ ${ }^{4}$ Universitas Negeri Makasar \\ Email: rosdiahsalam@unm.ac.id
}

\begin{abstract}
Abstrak
Pertanyaan penelitian dalam penelitian ini adalah bagaimana Kesulitan Guru dalam Mengembangkan Indikator Pembelajaran Kurikulum 2013SDN 210 Bottopenno. Penelitian ini adalah penelitian kualitatif denganSubjek penelitian yaitu guru kelas I, II, III, IV, V, dan VI.Pengumpulan data menggunakan pedoman wawancara dan dokumentasi. Teknik analisis data yaitu reduksi data, tahap penyajian data, dan penarikan kesimpulan. Hasil penelitian yang diperoleh yaitu guru kesulitan dalam menjabarkan KD kedalam indikator, menentukan Kata Kerja Operasional (KKO) yang sesuai, menentukan dan menyesuaikan kompetensi yang sesuai dengan karakteristik siswa, mengidentifikasi kemampuan yang dimiliki siswa, menentukan kegiatan pembelajaran sesuai dengan indikator yang dibuat, menentukan jenis penilaian yang sesuai dengan indikator yang di terapkan, dan kurangnya pelatihan mengenai penyusunan RPP Kurikulum 2013 yang sesuai dengan kondisi dan karakteristik setiap daerah. Kesimpulan dalam penelitian ini bahwa guru kelas SDN 210 Bottopenno dalam mengembangkan indikator pembelajaran guru kesulitan dalam 1) menjabarkan kompetensi dasar $K D, 2$ ) menentukan KKO, 3) menentukan kompetensi, 4) mengidentikasi karakteristik siswa, 5) menentukan kegiatan pembelajaran, 6) menentukan jenis penilaian dan 7) kurangnya pelatihan Kurikulum 2013 yang sesuai dengan kondisi dan karakteristik.
\end{abstract}

Kata kunci: Kesulitan Guru; Indikator; Kurikulum 2013.

\section{Abstract}

The research question in this study is how difficult the teacher is in developing the 2013 Curriculum Learning Indicators at SDN 210 Bottopenno. This research is a qualitative research with research subjects namely teachers of grades I, II, III, IV, V, and VI. Data collection using interview guidelines and documentation. Data analysis techniques are data reduction, data presentation stage, and drawing conclusions. The results obtained are that the teacher has difficulty in translating KD into indicators, determining the appropriate Operational Verbs (KKO), determining and adjusting competencies according to the characteristics of students, identifying the abilities of students, determining learning activities according to the indicators made, determining the type of assessment that is in accordance with the indicators applied, and the lack of training regarding the preparation of the 2013 Curriculum RPP that is in accordance with the conditions and characteristics of each region. The conclusion in this study is that the teacher of SDN 210 Bottopenno class in developing teacher learning indicators has difficulty in 1) describing basic basic competencies, 2) determining KKO, 3) determining competence, 4) identifying student characteristics, 5) determining learning activities, 6) determining the type of learning activity. assessment and 7) lack of 2013 Curriculum training in accordance with the conditions and characteristics.

Keywords:Teacher Difficulty; Indicator; Curriculum2013 


\section{PENDAHULUAN}

Pendidikan merupakan proses perubahan sikap dan perilaku seseorang dalam mendewasakan diri melalui kegiatan belajar yang berlansung seumur hidup, dapat pula dikatakan bahwa pendidikan adalah suatu usaha untuk mengembangkan atau membina manusia baik dari segi jasmani maupun rohani. Hal ini sesuai dengan UU No. 20 Tahun 2003 tentang Sistem Pendidikan Nasional Bab 1 Pasal 1 Ayat 1 bahwa Pendidikan adalah usaha sadar dan terencana untuk mewujudkan suasana belajar dan proses pembelajaran agar peserta didik secara aktif mengembangkan potensi dirinya untuk memiliki kekuatan spiritual, keagamaan, pengendalian diri, kepribadian, kecerdasan akhlak mulia, serta keterampilan yang diperlukan dirinya, masyarakat, bangsa dan negara (Depdiknas, 2003).

Pelaksanaan proses pendidikan di jenjang sekolah dasar telah mengalami perubahan yang signifikan, kurikulum yang diterapkan saat ini adalah kurikulum 2013 dengan istilah pendidikan karakter, (Mulyasa: 2020) mengatakan bahwa "Kurikulum 2013 adalah kurikulum yang menekankan pada pendidikan karakter, terutama pada tingkat dasar yang akan menjadi fondasi pada tingkat berikutnya". Implementasi Kurikulum 2013 yang mejadi rujukan proses pembelajaran pada satuan pendidikan, perlu mengintegrasikan Penguatan Pendidikan Karakter (PPK).

Integrasi tersebut sebagai satu kesatuan dalam mendidik dan belajar bagi bagi seluruh pelaku pendidikan di Indonesia, Hal ini sesuai dengan Peraturan Presiden Nomor 87 Tahun 2017 tentang Penguatan Pendidikan Karakter (PPK) pada Bab 1 Pasal 1 bahwa "...gerakan pendidikan dibawah tanggung jawab satuan pendidikan untuk memperkuat karakter peserta didik melalui harmonisasi olah hati, olah rasa, olah pikir dan olah raga dengan pelibatan dan kerja sama antara satuan pendidikan, keluarga dan masyarakat sebagai bagian dari Gerakan Nasional Revolusi Mental (GNRM)".

Perpres tersebut menjadi landasan awal untuk kembali meletakkan pendidikan karakter sebagai jiwa dalam penyelenggaraan pendidikan di Indonesia. Kemudian diperkuat dengan dikeluarkannya Permendikbut Nomor 20 Tahun 2018 tentang Penguatan Pendidikan Karakter (PPK) pada Satuan Pendidikan Formal.

Perubahan kurikulum di Indonesia berdampak pada setiap jenjang pendidikan sekolah, termasuk Sekolah 
Dasar (SD). Hal tersebut berdampak Nasional pada Pasal 3 bahwa pada setiap proses pembelajaran Pendidikan nasional berfungsi termasuk standar evaluasi yang mengembangkan kemampuan dan digunakan, dalam hal ini perlu membentuk watak serta peradaban pengembangan yang tepat dan sesuai bangsa yang bermartabat dalam rangka sasaran terkait dengan proses mencerdaskan kehidupan bangsa, pengembangan indikator pembelajaran bertujuan untuk berkembangnya potensi atau indikator pencapaian kompetensi di Sekolah Dasar (SD). (Kuntari: 2014) menegaskan bahwa perubahan kurikulum berimplikasi pada penacapain kualitas sumber daya manusia, perubahan kurikulum akan berdampak pada perubahan sistem dan proses pembelajaran, maka dengan ini salah satu poin penting adalah penyusunan indikator yang bersumber dari pemetaan Kompetensi Dasar (KD) pada setiap level pembelajaran. dalam kegiatan pembelajaran perubahan kurikulum berdampak secara "sistemik", baik dalam dalam penyusunan RPP maupun pemetaan indikator pada saat praktik.

Guru sebagai pendidik pada jenjang satuan pendidikan memiliki peran yang sangat penting dalam menentukan keberhasilan peserta didik, sehingga menjadi determinan peningkatan kualitas pendidikan disekolah. Pentingnya peran guru dalam pendidikan diamanatkan dalam UndangUndang Republik Indonesia Nomor 20 Tahun 2003 tentang Sistem Pendidikan peserta didik agar menjadi manusia yang beriman dan bertakwa kepada Tuhan Yang Maha Esa, berakhlak mulia, sehatt, berilmu, cakap, Kreatif, mandiri dan menjadi warga negara yang demokratis serta bertanggung jawab.

Dengan demikian sangat jelas fungsi guru yaitu mengembangkan kemampuan peserta didik dalam meningkatkan kualitas pendidikan di Indonesia. Permasalahan yang kemudian muncul salah satunya adalah masalah dalam pengembangan indikator pembelajaran tertentu yang perlu dikaji ulang agar sesuai dengan tujuan dari pendidikan dalam hal ini tujuan pembelajaran.

Indikator pembelajaran Sesuai dengan Peraturan Menteri Pendidikan dan Kebudayaan Republik Indonesia No. 103 Tahun 2014 tentang Pembelajaran pada Pendidikan Dasar dan Pendidikan menengah pasal 3 ayat 4 yaitu "Kemampuan yang dapat diobservasi untuk disimpulkan sebagai pemenuhan Kompetensi Dasar pada Kompetensi Inti 
1 dan Kompetensi Inti 2; b). Kemampuan yang dapat diukur dan/atau diobservasi untuk disimpulkan sebagai pemenuhan Kompetensi Dasar pada Kompetensi Inti 3 dan Kompetensi Inti 4".

Berdasarkan uraian diatas, dapat disimpulkan bahwa indikator pembelajaran merupakan sesuatu yang dapat di observasi atau diukur kemudian disimpulkan untuk memenuhi ketercapaian dari tujuan pembelajaran. Hal ini sejalan dengan pendapat Harso dkk mengatakan bahwa indikator berguna untuk menyukseskan sebuah proses pembelajaran sehingga tujuan pembelajaran tercapai dengan waktu yang diinginkan (Ernawati \& Safitri: 2018).

Dalam pengembangan indikator pembelajaran perlu mempertimbangkan beberapa hal, seperti 1) menentukan kompetensi yang dapat dilihat melalui KKO yang digunakan dalam KD, 2) karakteristik mata pelajarn, peserta didik dan sekolah, dan 3) potensi dan kebutuhan peserta didik, masyarakat dan lingkungan. Selanjutnya pengembangan indikator pembelajaran memerlukan informasi karakteristik peserta didik yang unik dan beragam, oleh karena itu indikator pembelajaran perlu mengakomodir keberagaman tersebut seperti 1) menganalisis kebutuhan dan potensi, 2) merumuskan indikator, dan 3) mengembangkan indikator peneilaian.

Berdasarkan hasil wawancara tidak terstruktur yang peneliti lakukan pada tanggal 4 Agustus 2021 dengan guru kelas II SDN 210 Bottopenno yaitu SSN, diperoleh informasi bahwa kesulitan yang dialami guru dalam mengembangkan indikator pembelajaran yaitu mulai dari aspek kesiapan pembelajaran terutama pada proses penyusunan instrumen penilaian berupa kesulitan dalam menjabarkan KD kedalam indikator, guru juga kesulitan dalam menentukan jenis penilaian yang tepat sesuai materi dalam KD. Tahapan persiapan sebelumnya penting karena akan sangat menentukan bagaimana proses inti pembelajaran nantinya berlansung.

Standar nasional pendidikan yang merupakan kriteria minimal tentang sistem pendidikan di indonesia, memiliki 8 standar meliputi Standar Kompetensi Lulusan, Standar Isi, Standar Proses, Standar Pendidikan dan tenaga kependidikan, Standar Sarana dan prasarana, Standar pengelolaan, Standar Pembiayaan Pendiddikan dan Standar Penilaian Pendidikan. Permasalahan guru dalam kurikulum 2013 khususnya guru SDN 210 Bottopenno Kecamatan Majauleng 
Kabupaten Wajo berada pada Standar Proses yang meliputi perencanaan proses pembelajaran terdiri atas Silabus, RPP, dan Prinsi Penyusunan RPP, sebagaimana yang diungkapkan kepala sekolah SDN 210 Bottopenno bahwa guru telah membuat Rencana Pelaksanaan Pembelajaran (RPP), akan tetapi belum menguasai komponenkomponen yang ada didalamnya, terlebih pada bagian indikator pembelajaran. guru diharapkan berupaya mengembangkan wawasan terkait tentang pemahaman Kata Kerja Operasional (KKO) dalam menyususn indikator pembelajaran.

Hal ini sejalan dengan penelitian sebelumnya yang dilakukan oleh Sri Hartini mengenai pengembangan indikator yang dibuat guu, bahwa 1) guru belum mampu membedakan antara indikator pembelajaran dan tujuan pembelajara, 2) guru belum memahami penggunaan Kata Kerja Operasional (KKO) yang harus digunakan dalam mengembangkan indikator, 3) guru belum memahami hubungan antara indikator dengan kompetensi dasar yang dikembangkan, dan 4) guru belum memiliki kesamaan persepsi tentang tujuan, makna dan sistem pengembangan indikator.

Berdasarkan konteks di atas, fokus dalam penelitian ini adalah bagaimana kesulitan guru dalam mengembangkan indikator pembelajaran, oleh karena itu untuk mengkaji lebih lanjut diperlukan kajian penelitian yang mendalam, maka peneliti melaksanakan penelitian dengan judul "Analisis Kesulitan Guru dalam Mengembangkan Indikator Pembelajaran Kurikulum 2013 SDN 210 Bottopenno Kecamatan Majauleng Kabupaten Wajo".

\section{METODE PENELITIAN}

Jenis Penelitian yang digunakan dalam penelitian ini adalah penelitian kualitatif. Menurut (Warul: 2015) bahwa penelitian kualitatif merupakan suatu proses penelitian untuk memahami masalah masalah manusia atau sosial dengan menciptakan gambaran menyeluruh dan kompleks yang disajikan dengan kata kata, melaporkan pandangan terinci yang diperoleh dari para sumber informasi, serta dilakukan dengan ilmiah.

Penelitian dilaksanakan maksimal selama 5 bulan dimulai pada pertengahan bulan Maret dan berakhir pada bulan Agustus tahun 2021. Penelitian ini dilaksanakan di salah satu lembaga pendidikan Kabupaten Wajo, yaitu di SDN 210 Bottopenno yang berlokasi di Jalan Poros Palopo Desa Bottopenno Kecamatan Majauleng Kabupaten Wajo Provinsi Sulawe si Selatan. 
Pelaksanaan pengumpulan data penelitian ini dilaksanakan kurang lebih selama sebulan dengan rincian sekolah diamati secara penuh selama kurang lebih satu minggu. Selanjutnya melakukan wawancara bersama guru untuk memperoleh informasi dan pengambilan data. Data yang dikumpulkan berupa data arsip. Prosedur penelitian disusun dengan uraian sebagai berikut : (1) Melakukan pra penelitian, (2) Menentukan Partisipan yang akan diwawancarai, Menentukan dokumen apa yang harus didapatkan, (4) Melakukan pengumpulan data (5) Menentukan analisis data (6) Merencanakan pemeriksaan keabsahan data, (7) melakukan analisis akhir dan membuat interpretasi data dan kesimpulan penelitian (8) Membuat laporan akhir Penelitian.

Teknik pengumpulan data merupakan langkah yang paling utama dalam penelitian, karena tujuannya yaitu untuk mendapatkan data yang digunakan. Teknik pengumpulan data yang digunakan dalam penelitian ini adalah teknik wawancara, dan dokumentasi. Wawancara yang digunakan dalam penelitian ini untuk memperoleh informasi melalui tatap muka. Wawancara yang dilakukan pada penelitian ini yaitu wawancara tersruktur.
Sedangkan dokumentasi dalam penelitian ini untuk mendapatkan gambar atau informasi yang jelas berupa RPP.

Teknik analisis data yang digunakan dalam penelitian ini adalah teknik analisis yang dikembangkan oleh Miles dan Huberman mengatakan bahwa aktivitas dalam analisis data kualittatif dilakukan secara interaktif dan berlangsung secara terus menerus sampai tuntas, sehingga datanya sudah jenuh, yaitu data reduction, data display, dan congclucion drawing/verification" (Sugiyono: 2020: 133).

\section{HASIL DAN PEMBAHASAN}

\section{Hasil Wawancara.}

\section{Fungsi Indikator Pembelajaran dalam RPP}

Indikator pembelajaran menjadi tolak ukur yang akan dicapai dalam pembelajaran, indikator menjabarkan kompetensi dasar kedalam unit-unit kompetensi yang lebih rinci. Ketika peserta didik sudah mampu melakukan semua unit kompetensi berarti peserta didik telah menguasai kompetensi dasar yang telah dipelajarinya. Berdasarkan hasil wawancara mengenai apa fungsi indikator pembelajaran dalam sebuah RPP, dikemukakan hasil wawancara dengan subjek pertama selaku guru kelas I sebagai berikut : 
"Fungsi indikator pembelajaran dalam RPP yaitu tentu sebagai suatu pedoman untuk mengembangkan pembelajaran, sebagai pedoman untuk menyusun kegiatan yang akan dilakukan dalam pembelajran dan sebagai pedoman dalam membuat penilaian belajar".(S1MIP 07 Agustus 2021)

Peneliti kemudian menambahkan bahwa:

"Jadi seperti itu bu', sedikit saya tambahkan bu mengenai fungsi indikator dalam RPP, selain 3 poin yang ibu sebutkan tadi, fungsi lain indikator juga sebagai penanda bahwa dikuasai atau tidaknya kompetensi dasar atau KD dan sebagai acuan bagi ibu dalam menyusun instrumen penilaian".(Peneliti 07 Agustus 2021)

“lye dek”.(S1MIP 07 Agustus 2021)

Sejalan dengan pendapat subjek pertama, subjek kedua selaku guru kelas II dalam wawancara mengemukakan hal yang sama bahwa :

".... tentu untuk mengembangkan bahan ajar dan materi pembelajaran, untuk mendesain pembelajaran dan untuk merancang dan melaksanakan penilaian hasil belajar".(S2MIP 07 Agustus 2021)

Hal yang berbeda kemudian dikemukakan oleh subjek ke 3 selaku guru kelas III mengemukakan bahwa :

"Fungsi indikator pembelajaran dalam rpp yaitu sebagai standar ketercapaian materi dalam proses pembelajaran."(S2MIP 08 Agustus 2021)
Peneliti kemudian menambahkan bahwa:

"Menurut ibu bahwa fungsi indikator dalam RPP sebagai standar ketercapaian materi dalam pembelajaran, berarti ini sudah termasuk seperti KD yang akan dikuasai ?"(Peneliti 08 Agustus 2021)

"iye dek sudah termasuk KD yang akan dikuasai juga, karena KD kan kompetensi dasar atau awal yang akan dicapai."(S2MIP 08 Agustus 2021)

"Saya rasa bu fungsi indikator juga bisa sebagai atau acuan untuk ibu dalam menentukan kemudian tujuan pembelajaran."(Peneliti 08 Agustus 2021)

“lye dek"(S2MIP 08 Agustus 2021)

Kemudian pendapat berbeda juga dikemukakan oleh subjek keempat selaku guru kelas IV yang mengemukakan bahwa:

"Menurut saya fungsi indikator pembelajaran dalam RPP adalah memberikan batasan dan mengarahkan pembelajaran secara nurut dan sistematis sehingga kompetensi pembelajaran dapat dicapai".(S4MIP 08 Agustus 2021) "jadi yang bisa tangkap, bahwa menurut ibu fungsi indikator itu untuk lebih mempermudah tujuan dari pembelajaran tercapai, seperti itu bu ?".(Peneliti 08 Agustus 2021) "iye tepat sekali dek, mungkin seperti itu yang saya maksud"(S4MIP 08 Agustus 2021)

Sementara itu, subjek kelima selaku guru kelas $\mathrm{V}$ mengemukakan bahwa, ada 3 fungsi indikator pembelajaran dalam RPP sebagaimana 
disebutkan dalam wawancara sebagai berikut :

"Fungsi indikator pembelajaran dalam RPP yaitu sebagai pedoman dalam mengembangkan materi pembelajaran, sebagai pedoman mengembangkan materi ajar, dan sebagai pedoman dalam merancang dan melaksanakan penilaian hasil belajar".(S5MIP 09 Agustus 2021)

Pendapat yang sama juga disampaikan oleh subjek keenam selaku guru kelas VI, sebagaimana hasil petikan wawancara berikut :

“..pertama sebagai pedoman untuk mengembangkan suatu materi pembelajaran, kemudian sebegai pedoman juga bagi guru untuk mendesain kegiatan pembelajaran dan yang terkahir sebagai pedoman bagi guru dalam merancang dan melaksanakan penilaian hasil belajar atau evaluasi pembelajaran".(S6MIP 09 Agustus 2021).

\section{Berdasarkan hasil wawancara}

diatas mengenai fungsi indikator, maka dapat disimpulkan bahwa fungsi indikator pembelajaran dalam Rencana Pelaksanaan pembelajaran (RPP) yaitu sebagai pedoman bagi guru untuk mengembangkan materi pembelajaran, sebagai pedoman untuk menyusun dan mengembangkan kegiatan pembelajran, sebagai pedoman dalam merancang, membuat dan melaksanakan penilaian belajar, sebagai standar ketercapaian materi dalam proses pembelajaran, dan untuk lebih mempermudah tujuan dari pembelajaran tercapai.

\section{Kriteria Indikator yang baik dan benar.}

Berdasarkan hasil wawancara mengenai kriteria indikator pembelajaran yang baik dan benar, guru sebagai subjek atau narasumber mengemukakan pendapat yang berbeda-beda. Adapun hasil wawancara dengan subjek pertama selaku guru kelas I mengatakan bahwa :

"Menurut saya kriteria indikator yang baik yaitu yang pertama memuat ciri-ciri KD yang akan diukur, kemudian memuat KKO yang dapat diukur juga serta harus berkaitan dengan materi dalam pelajaran yang dipilih".(S1MIP 07 Agustus 2021)

Subjek keenam berpendapat sedikit berbeda bahwa :

"Kriteria indikator yang benar yaitu memuat ciri-ciri kompetensi yang jelas dan dapat diukur, kedua memuat KK yang bisa di ukur, selanjutnya berkaitan dengan bahan ajar serta dapat dibuat soalnya".(S6MIP 09 Agustus 2021)

Pendapat yang senada dikemukakan juga oleh subjek kedua selaku guru kelas II, sebagaimana hasil petikan wawancara sebagai berikut :

“.... perlu memiliki ciri-ciri yang ada pada KD yang akan diukur, kemudian memuat kata kerja yang 
dapat diukur juga serta harus ada kaitan antara indikator dan materi dalam pelajaran yang akan dipilih."(S2MIP 07 Agustus 2021)

Peneliti kemudian menambahkan bahwa:

"Jadi menurut ibu kriteria indikator yang baik itu harus memiliki 2 point tersebut, kalau menurut saya bu, sesuai dengan yang saya ketahui dan yang saya sudah baca bahwa kriteria indikator yang baik dan benar itu perlu juga mengaitkan antara indikator dengan bahan ajar dan dapat juga dibuatkan soal karena indikatorkan sebagai penanda ketercapaian suatu pembelajaran".(Peneliti 07 Agustus 2021)

“lye dek".(S2MIP 07 Agustus 2021)

Kemudian guru kelas IV selaku

subjek keempat berpendapat bahwa :

"Menurut saya dan menurut apa yang saya pernah baca, kriteria indikator yang baik dan benar yaitu memuat ciri-ciri KD, memuat kata kerja ,juga serta harus berkaitan dengan materi dalam pelajaran yang dipilih.

".... yang bisa saya simpulkan bahwa indikator yang baik itu pertama indikator perlu menggunakan bahasa yang jelas dan baik, kemudian tujuan kompetensi yang ingin dicapai tidak ambigu dan terakhir membuat pembelajaran terlaksana secara sistematis, terarah dan efektif'.(S4MIP 08 Agustus 2021)

Sementara itu subjek ketiga selaku guru kelas III mengungkapkan hal yang berbeda bahwa :
"Indikator yang baik dan benar menurut saya yaitu yang mampu menggambarkan suatu ketercapaian minimal dalam suatu materi atau pembelajaran."(S3MIP 08 Agustus 2021)

"ibu mengatakan bahwa indikator yang baik dan benar itu mampu menggambarkan suatu ketercapaian materi, seperti apa yang ibu maksut itu?".(Peneliti 08 Agustus 2021)

“.... artinya indikator ini mampu menggambarkan apa yang perlu dicapai oleh siswa.(S4MIP 08 Agustus 2021)

"jadi indikator yang baik dan benar itu harus dapat menggambarkan apa yang ingin dicapai oleh siswa".(Peneliti 08 Agustus 2021) “lye dek".(S4MIP 08 Agustus 2021)

Selanjutnya subjek kelima mengungkapkan hal yang berbeda bahwa:

"Kriteria indikator yang benar setau saya adalah ketika indikator itu mampu menjadi tolak ukur untuk mengukur tercapaianya kompetensi dasar, kemudian yang kedua yaitu menggunakan kata kerja operasional yang jelas, dan yang terakhir yaitu indikator harus dapat diukur dan diamati”.'(S5MIP 09 Agustus 2021)

Berdasarkan hasil wawancara di atas, keenam subjek penelitian menyatakan pendapat yang berbedabeda, maka peneliti menyimpulkan hasil wawancara tersebut. Bahwa kriteria indikator yang baik dan benar perlu memuat ciri-ciri kompetensi dasar yang jelas dan dapat diukur, memuat kata 
kerja operasional yang dapat diukur, berkaitan antara indikator dengan materi dalam mata pelajaran yang dipilih, dapat dibuat soalnya, disisi lain guru mengungkapkan bahwa indikator yang baik dan benar perlu menggunakan bahasa yang jelas dan baik, kemudian tujuan kompetensi yang ingin dicapai tidak ambigu dan membuat pembelajaran terlaksana secara sistematis, terarah dan efektif, serta mampu menjadi tolak ukur untuk mengukur tercapaianya kompetensi dasar.

\section{Cara Mengembangkan Indikator} Pembelajaran Kurikulum 2013

Proses

guru

dalam

mengembangkan indikator menjadi faktor penting dalam merumuskan rencana pembelajaran yang akan diajarkan, walaupun indikator sejatinya telah dituangkan dalam buku guru dan buku siswa akan tetapi guru perlu mengembangkan indikator agar dapat menyesuaikan dengan karakteristik, potensi serta kebutuhan siswa, indikator dalam hal ini perlu dikembangkan agar tujuan pembelajaran yang akan dicapai dapat sesuai dengan yang diharapkan. Cara guru dalam mengembangkan indikator pembelajaran di SDN 210 Bottopenno diunkapkan dalam petikan wawancara oleh subjek pertama yaitu guru kelas I sebagai berikut :

"Untuk mengembagkan indikator agar sesuai dengan yang diinginkan siswa tentu kita perlu menyesuaikan terlebih dahulu kompetensi yang ada pada KKO yang digunakan dalam KD, kemudian memperhatikan karakteristik mata pelajaran peserta didik, selain itu kita juga perlu melihat potensi dan kebuthan peserta didik agar selaras dengan tujuan yang akan kita capai kemudian".(S1MIP 07 Agustus 2021)

Sejalan dengan yang ungkapkan subjek pertama, subjek kedua yaitu guru kelas II juga mengungkapkan pendapat yang sama yang lebih jelas bahwa :

“.... yang pertama dilakukan adalah menganalisis tingkat kompetensi yang ada pada SK dan KD, selanjutnya menganalisis karakteristik materi, peserta didik dan sekolah, yang terakhir menganalisis kebutuan dan potensi yang dimiliki siswa".(S2MIP 07 Agustus 2021)

Subjek kelima juga menyatakan hal yang sama bahwa :

“... melihat karakteristik siswa, kemudian mata pelajaran, satuan pendidikan maupun potensi daerah, setelah semua itu dipertimbangkan maka dicarilah kalimat yang sesuai agar dapat mendukung karakteristik siswa".(S5MIP 09 Agustus 2021) 
Berbeda halnya dengan subjek kedua, subjek ketiga selaku guru kelas III mengatakan bahwa :

“... terlebih dahulu saya merumuskan standar kompetensi atau kompetensi minimal dengan kemampuan dan kebutuhan siswa dalam belajar".(S3MIP 08 Agustus 2021)

"Jadi pertama ibu lakukan adalah merumuskan SK dan KD. Apakah sebelum ibu merumuskan SK dan KD yang akan diajarkan kepada siswa, ibu tidak menganalisisnya terlebih dahulu?".(Peneliti 08 Agustus 2021)

"tentu diadakan terlebih dahulu pengkajian dek sebelum merumuskannya".(S3MIP 08 Agustus 2021)

"Iye bu, saya rasa hal itu perlu ibu lakukan terlebih dahulu".(Peneliti 08 Agustus 2021)

“lye dek”.(S3MIP 08 Agustus 2021)

Sementara itu subjek keempat yaitu guru kelas IV mengungkapkan hal yang berbeda bahwa :

".... saya menentukan terlebih dahulu apa yang harus ada dalam pembelajaran dan memikirkan atau melakukan pemetaan kognitif dan waktu yang akan dicapai oleh peserta didik.

“... memperjelas penguasaan kompetensi yang ingin dicapai dalam $\mathrm{KI}$ dan KD sesuai dengan kebutuhan peserta didik".(S4MIP 08 Agustus 2021)

Kemudian peneliti menambahkan bahwa :

"Seperti itu yah bu, jadi terlebih dahulu ibu menentukan apa yang akan dilakukan oleh siswa, kemudian melakukan pemetaan kognitif dan waktu, dengan tujuan untuk memperjelas penguasaan kompetensi yang akan dicapai oleh KI dan KD".(Peneliti 08 Agustus 2021)

“lye dek".(S4MIP 08 Agustus 2021)

Hal berbeda diungkapkan oleh subjek kelima selaku guru kelas VI mengungkapkan bahwa :

"Dalam mengembangkan indikator pembelajaran kita perlu terlebih dahulu menganalisis standar kompetensi, apabila kemudian KD yang tersedia pada standar kompetensi belum mampu mengakomodir seluruh amanat yang terdapat pada standar kompetensi kita manambah rumusan KD sehingga semua amanat dalam SK dapat diakomodir".(S6MIP 09 Agustus 2021)

"Berarti KD yang ada pada SK harus terpenuhi agar guru tidak menambah lagi rumusan pada KD”.(Peneliti 09 Agustus 2021)

"lye dek, karena jika tidak terpenuhi, akan menambah lagi pekerjaan guru".(S6MIP 09 Agustus 2021)

Berdasarkan hasil petikan wawancara di atas mengenai cara guru dalam mengembangkan indikator pembelajaran, maka disimpulkan bahwa guru dalam mengembangkan indikator pembelajaran yaitu pertama menganalisis tingkat kompetensi yang ada pada SK dan KD, selanjutnya menganalisis karakteristik materi, peserta didik dan sekolah, menganalisis kebutuan dan potensi yang dimiliki siswa, melihat potensi dan kebutuhan 
peserta didik agar selaras dengan tujuan yang akan kita capai kemudian. sementara itu diungkapkan guru bahwa perlu menentukan terlebih dahulu apa yang harus ada dalam pembelajaran dan memikirkan atau melakukan pemetaan kognitif dan waktu yang akan dicapai oleh peserta didik

\section{Kesulitan Guru dalam Mengembangkan Indikator}

\section{Pembelajaran Kurikulum 2013}

Guru dalam mengembangkan indikator pembelajaran memiliki kendala atau kesulitan yang kemudian muncul dalam proses pengembangan indikator. Berdasarkan hasil wawancara, ada berbagai macam kesulitan yang dihadapi guru dalam mengembangkan indikator pembelajaran kurikulum 2013, Pertanyaan yang diajukan melalui wawancara kepada subjek penelitian yaitu guru kelas 1 sebagai subjek pertama sebagaimana hasil petikan wawancara berikut ini :

"Mengenai kesulitan saya dalam
mengembangkan indikator
pembelajaran tentu banyak, salah
satunya itu saya kesulitan dalam
menentukan kata kerja operasional
yang akan digunakan." (S1MIP 07
Agustus 2021)

Peneliti kemudian menambahkan bahwa:
"Yang menjadi kesulitan ibu dalam mengembangkan indikator pembelajaran berada pada penentuan KKO, apakah yang menjadi kendala ibu sehingga KKO sulit untuk menentukan dalam pengembangkan indikator ?".(Peneliti 07 Agustus 2021)

"Saya mengatakan seperti itu karena kita untuk menentukan KKO perlu melihat karakteristik yang diinginkan oleh siswa, ini juga menjadi tumpuan ibu dalam menentukan seperti apa kemudian penilaian yang akan dibuat". (S1MIP 07 Agustus 2021)

"jadi untuk menentukan KKO perlu melihat karakteristik yang diinginkan oleh siswa yah bu ?".(Peneliti 07 Agustus 2021)

"Betul sekali dek" (S1MIP 07 Agustus 2021)

Hal senada juga diungkapkan oleh Guru kelas II selaku subjek kedua tentang kesulitan dalam mengembangkan indikator pembelajaran yaitu ketika akan menentukan Kata Kerja Operasioanl (KKO), sebagaimana yang diutarakan sebagai berikut :

“.... kesulitan dalam menentukan kata kerja operasional yang akan digunakan, kesulitan lainnya yaitu karakteristik siswa berbeda-beda sehingga ketika ingin menentukan jenis penilian sulit". (S2MIP 07 Agustus 2021)

Peneliti menambahkan bahwa :

"Kesulitan yang ibu alami dalam mengembangan indikator dimana pada penentuan jenis penilaian karena karakteristik yang diinginkan siswa, kemudian bu yang saya ketahui ada 3 macam jenis 
penilaian bu, pertama penilaian sikap, penilaian pengetahuan dan keterampilan. Pertanyaan saya penilaian jenis apa yang membuat ibu kesulitan dalam menentukan penilaian ?". (Peneliti 07 Agustus 2021)

"Baik, jenis penilaian yang sulit saya tentukan yaitu jenis penilaian sikap, karena penilaian sikap memiliki 2 macam penillian yang harus ditentukan, yang pertama sikap sosial dan sikap spiritual siswa, dalam 2 point ini masih terdapat 3 penilaian lagi didalamnya dek, seperti observasi, penilaian diri sendiri dan penilaian antar teman, seperti itu dek". (S2MIP 07 Agustus 2021)

"Jadi ibu menemukan kesulitan dalam menentukan penilaian pada jenis penilaian sikap, karena selaian berkaitan lansung dengan karakteristik siswa tetapi juga memiliki 3 point peilaian didalamnya seperti observasi, penilaian diri sendiri dan penilaian antar teman".(Peneliti 07 Agustus 2021

"Iye dek".(S2MIP 07 Agustus 2021)

Sementara itu hal baru juga

dikemukakan oleh subjek kedua bahwa :

“.... minimnya pelatihan atau sosialisasi tentang pembuatan RPP dalam hal ini indikator pembelajaran pada kurikulum 2013 menjadikan kita kurang pengetahuan dalam membuat atau mengembangkan ketercapaian yang diinginkan oleh siswa". (S2MIP 07 Agustus 2021)

"Jadi bu' apakah dengan adanya pelatihan-pelatihan tentang kurikulum 2013 akan menjadi penambal dari kendala yang ibu hadapi kedepan ?". (Peneliti 07 Agustus 2021)
"Insya Allah dek, karena kita selaku guru perlu juga terus belajar"(S2MIP 07 Agustus 2021)

Guru kelas III selaku subjek ketiga mengungkapkan hal yang berbeda dengan subjek pertama dan kedua, sebagaimana petikan berikut :

"Kalau kendala atau kesulitan saya dalam mengembangkan suatu indikator yaitu, secara umum sangat sulit diidentifikasi potensi atau kemampuan siswa sehingga terkadang indikator yang dikembangkan kurang tepat dengan gaya dan kemampuannya" (S3MIP 08 Agustus 2021) "dengan tidak tepatnya indikator yang ibu buat dengan potensi siswa, apakah ibu tidak menggunakan indikator pendukung dalam indikator pembelajaran?"(Peneliti 08 Agustus 2021)

"lye dek, saya tidak menggunakan indikator pendukung"(S3MIP 08 Agustus 2021)

"Saya rasa ibu perlu menggunakan indikator pendukung karena indikator pendukung dapat membantu siswa memahami dan mengerti tentang indikator kunci atau indikator utama ibu"(Peneliti) "Iye dek"(S3MIP 08 Agustus 2021)

Sementara itu, hasil wawancara oleh guru kelas IV selaku subjek keempat mengatakan bahwa :

"Kendala ataupun kesulitan yang saya alami dalam mengembangkan indikator yaitu dimana kemampuan peserta didik yang berbeda-beda sehingga membuat kita bingung dalam menentukan kompetensi 
yang sesuai tanpa merugikan semua peserta didik dan sulit menentukan kegiatan pembelajaran sesuai indikator yang sudah saya tetapkan" (S4MIP 08 Agustus 2021).

Peneliti kemudian menambahkan bahwa :"Sesuai dengan jawaban ibu sebelumnya bahwa yang menjadi kesulitan ibu yaitu sulit menentukan kompetensi yang sesuai dengan karakteristik peserta didik, apakah ibu tidak menganalisis sebelumnya karakteristik peserta didik?"(Peneliti 08 Agustus 2021)

"Saya menganalisis dek, akan tetapi karakteristik siswanya beragam dan tidak semua saya dalami, jadi kompetensi yang saya tentukan belum sesuai dengan tujuan yang akan di capai". (S4MIP 08 Agustus 2021).

"Jadi ibu perlu menganalisis kembali karakteristik dan potensi yang dimiliki peserta didik agar ibu tidak kesulitan lagi dalam menentukan kompetensi, ".(Peneliti 08 Agustus 2021)

"lye dek. (S4MIP 08 Agustus 2021)

Hal berbeda juga diungkapkan oleh subjek kelima yaitu guru kelas $\mathrm{V}$ sebagaimana berikut :

"Kendala ataupun kesulitan yang saya alami yaitu kita kekurangan data tentang siswa dan sekolah sehingga dengan kekurangan data itu kita sulit menyesuaikan antara kebutuhan siswa atau kemampuannya dengan indikator yang kita buat, sehingga tidak sesuai antara indikator dengan apa yang diinginkan siswa atau potensi yang dimiliki siswa"(S5MIP 09 Agustus 2021)
Peneliti menambahkan bahwa :

"Kesulitan yang bapak alami yaitu kekurangan data tentang siswa sehingga indikator yang dibuat tidak sejalan dengan karakteristik atau kebutuhan yang dimiliki siswa, apakah bapak tidak menganalisis karakteristik siswa terlebih dahulu?".(Peneliti 09 Agustus 2021) "Saya sulit dalam menganalisis dek, karena terlalu banyak dan berbeda-beda karakternya, kita juga perlu melihat seperti bagaimana minatnya siswa, kemampuan berfikirnya sampai bagaimana lingkunganya, itu semua perlu dianalisis, inilah yang menjadi kesulitan bagi saya selaku guru, seperti itu dek."(S5MIP 09 Agustus 2021)

"Iye pak, jadi bagaimana bapak selama ini menganajar dengan kendala seperti yang disebutkan tadi?".(Peneliti 09 Agustus 2021)

"Kita mengajar sesuai apa yang ada dan yang sudah disediakan saja dek"(S5MIP 09 Agustus 2021) "lye pak".(Peneliti 09 Agustus 2021)

Sementara itu, subjek keempat yaitu guru kelas VI mengungkapkan hal yang berdeda bahwa:

“.... dalam mengembangkan indikator pembelajaran saya sulit dalam proses penyusuanan instrumen penilaian hasil belajar berupa kesulitan dalam penjabaran KD kedalam indikator, kesulitan dalam membuat kisi kisi instrumen penilaian, saya juga kesulitan dalam menentukan kata kerja yang sesuai dengan karakteristik siswa. (S6MIP 09 Agustus 2021) "ibu mengatakan bahwa ibu sulit dalam proses menyusun instrumen penilaian, seperti apa kesulitan yang ibu alami pada penyusunan 
instrumen?".(Peneliti 09 Agustus 20210

"saya sulit karena penilaian yang harus di lakukan itu banyak, seperti penilaian sikap, pengetahuan dan keterampilan, dengan karakter yang berbeda-beda dari siswa saya sulit menentukan yang mana yang sesuai dengan siswa".(S6MIP 09 Agustus 2021)

"jadi yang menjadi tolak ukur tetap pada karakteristik siswa yang berbeda-beda sehingga dalam mengembangkan sebuah indikator, ibu sulit menyusun instrumen penilaian untuk siswa, sedikit tambahan bu Saya rasa solusi yang bisa menuntaskan kesulitan ibu yaitu perlu adanya pelatihanpelatihan yang lebih banyak lagi serta ibu lebih mengasah lagi keterampilan, karena ini menyangkut tentang kompetensi ibu selaku guru, hal ini juga akan berdampak kepada anak didik ibu kedepannya".(Peneliti 09 Agustus 2021)

Berdasarkan hasil wawancara diatas yang dilakukan oleh peneliti, maka dapat disimpulkan bahwa dalam mengembangkan indikator pembelajaran terdapat beberapa kesulitan yang dialami oleh guru dalam mengembangkan indikator pembelajaran Kurikulum 2013 di SDN 210 Bottopenno Kecamatan Majauleng Kabupaten Wajo. Pertama guru kesulitan dalam merumuskan atau menjabarkan kompetensi dasar (KD) kedalam indikator, guru kesulitan menentukan Kata Kerja Operasional (KKO) yang sesuai dengan tingkat pemahaman atau ketercapaian siswa, guru kesulitan dalam menentukan dan menyesuaikan kompetensi yang sesuai dengan karakteristik dan potensi atau kemampuan siswa, guru kesulitan dalam mengidentifikasi kemampuan yang dimiliki siswa, guru kesulitan dalam menentukan kegiatan pembelajaran sesuai dengan indikator yang dibuat, guru juga kesulitan dalam menentukan jenis penilaian yang sesuai dengan indikator yang terapkan, dan guru mengatakan bahwa salah satu yang menjadi kendala dalam mengembangkan indikator pembelajaran yaitu kurangnya pelatihan mengenai penyusunan RPP Kurikulum 2013 yang sesuai dengan kondisi dan karakteristik setiap daerah

\section{PEMBAHASAN}

\section{Fungsi Indikator Pembelajaran dalam RPP}

Berdasarkan temuan peneliti di SDN 210 Bottopenno Kecamatan majauleng Kabupaten Wajo dari hasil deskripsi dan hasil wawancara yang telah dilakukan dengan subjek S1MIP, S2MIP, S3MIP, S4MIP, S5MIP, dan S6MIP maka ditemukan bahwa fungsi indikator pembelajaran dalam RPP yang pertama yaitu sebagai pedoman bagi guru untuk mengembangkan materi pembelajaran, sebagai pedoman untuk menyusun dan mengembangkan kegiatan pembelajran, sebagai pedoman dalam merancang, 
membuat dan melaksanakan penilaian belajar, sebagai standar ketercapaian materi dalam proses pembelajaran, dan untuk lebih mempermudah tujuan dari pembelajaran tercapai.

Indikator pembelajaran memiliki kedudukan yang strategis dalam mengembangkan indikator berdasarkan SK dan KD, sesuai yang dikemukakan oleh guru sebelumnya, fungsi indikator pembelajaran dalam RPP sesuai dengan yang dikemukakan oleh Sudrajat (2011) bahwa fungsi indikator pembelajaran adalah 1) pedoman dalam mengembangkan materi pembelajaran, 2) Pedoman dalam mendesain kegiatan pembelajaran, 3) pedoman dalam mengembangkan bahan ajar, dan 4) pedoman dalam merancang dan melaksanakan penilaian hasil belajar.

\section{Kriteria Indikator yang Baik dan Benar}

Berdasarkan hasil wawancara diperoleh bahwa, Subjek penelitian menyatakan pendapat yang berbedabeda mengenai kriteria indikator yang baik dan benar, yang pertama kriteria indikator yang baik dan benar perlu memuat ciri-ciri kompetensi dasar yang jelas dan dapat diukur, memuat kata kerja operasional yang dapat diukur, berkaitan antara indikator dengan materi dalam mata pelajaran yang dipilih, dapat dibuat soalnya, disisi lain guru mengungkapkan bahwa indikator yang baik dan benar perlu menggunakan bahasa yang jelas dan baik, kemudian tujuan kompetensi yang ingin dicapai tidak ambigu dan membuat pembelajaran terlaksana secara sistematis, terarah dan efektif, serta mampu menjadi tolak ukur untuk mengukur tercapaianya kompetensi dasar.

Berdasarkan

pembahasan

sebelumnya mengenai kriteria indikator yang baik dan benar oleh guru SDN 210 Bottopenno Kecamatan majauleng kabupaten Wajo sudah sesuai dengan yang ditertera padaDepartemen Pendidikan Nasional (2013) bahwa Kriteria indikator yang baik dan benar yaitu 1) memuat ciri-ciri KD yang hendak diukur, 2) memuat satu kata kerja operasional yang dapat diukur, 3) berkaitan erat dengan kompetensi dan materi pembelajaran, dan 4) soalnya dapat dibuat sesuai dengan bentuk yang telah ditetapkan pada kisi-kisi.

\section{Cara Guru Mengembangkan Indikator Pembelajaran Kurikulum 2013.}

Berdasarkan temuan peneliti, cara guru dalam mengembangkan indikator pembelajaran kurikulum 2013 berbedabeda, berdasarkan hasil wawancara 
ditemukan bahwa cara guru dalam mengembangkan indikator pembelajaran yaitu pertama menganalisis tingkat kompetensi yang ada pada SK dan KD, selanjutnya menganalisis karakteristik materi, peserta didik dan sekolah, menganalisis kebutuan dan potensi yang dimiliki siswa, melihat potensi dan kebutuhan peserta didik agar selaras dengan tujuan yang akan kita capai kemudian. sementara itu diungkapkan guru bahwa perlu menentukan terlebih dahulu apa yang harus ada dalam pembelajaran dan memikirkan atau melakukan pemetaan kognitif dan waktu yang akan dicapai oleh peserta didik.

Mengembangkan indikator menjadi poin penting dalam menyusun tujuan agar mudah dicapai, cara guru dalam mengembangkan indikator yang dibahas sebelumnya sejalan dengan yang dikemukakan oleh sulistianingsih (2013) bahwa langkah-langkah pengembangkan indikator pembelajaran yaitu 1) menganalisis tingkat kompetensi dalam SK dan KD, 2) menganalisis karakteristik mata pelajaran, peserta didik dan sekolah, 3) menganalisis kebutuhan dan potensi, 4) merumuskan indikator, dan 5) mengembangkan indikator penilaian

\section{Kesulitan Guru dalam Mengembangkan Indikator Pembelajaran Kurikulum 2013 SDN 210 Bottopenno Kecamatan Majauleng Kabupaten Wajo. \\ Berdasarkan temuan peneliti,} kesulitan yang dialami oleh guru pada saat mengembangkan indikator pembelajaran beda-beda, berdasarkan informasi dari wawancara guru-guru atau wali kelas bahwa guru kesulitan dalam merumuskan atau menjabarkan kompetensi dasar (KD) kedalam indikator, guru kesulitan menentukan Kata Kerja Operasional (KKO) yang sesuai dengan tingkat pemahaman atau ketercapaian siswa, Kesulitan tersebut sesuai dengan yang dikatakan Prastowo (2019, h. 35) bahwa indikator dirumuskan dengan menggunakan kata kerja oprasional mencakup dua hal yaitu tingkat kompetensi dan materi yang menjadi pencapaian kompetensi.

Guru kesulitan dalam menentukan dan menyesuaikan kompetensi yang sesuai dengan karakteristik dan potensi atau kemampuan siswa, guru kesulitan dalam mengidentifikasi kemampuan yang dimiliki siswa, guru kesulitan dalam menentukan kegiatan pembelajaran sesuai dengan indikator yang dibuat, guru juga kesulitan dalam menentukan jenis penilaian yang sesuai dengan indikator yang terapkan. Kesulitan yang dialami guru kelas SDN 210 Bottopenno 
memberi pengaruh besar dalam kemampuan guru mengembangkan indikator pembelajaran karena yang menjadi kesulitan adalah hal-hal yang dianggap sebagai kunci dalam mengembangkan indikator, sesuai dengan yang diungkapkan Ariyana (2018):

"Tentukanlah proses befikir yang akan dilakukan oleh peserta didik untuk mencapai kompetensi minimal yang ada pada $\mathrm{KD}, 2$ ) Rumusan indikator menggunakan KKO yang bisa diukur, 3) indikator dirumuskan dalam kalimat yang simpel, jelas, dan mudah dipahami, 4) tindak menggunakan kata yang bermakna ganda, 5) hanya mengandung satu tindakan dan satu materi, 6) memperhatikan karakteristik mata pelajaran, potensi dan kebutuhan siswa, sekolah masyarakat dan lingkungan".

Guru juga mengungkapkan bahwa salah satu yang menjadi kendala dalam mengembangkan indikator pembelajaran yaitu kurangnya pelatihan mengenai penyusunan RPP Kurikulum 2013 yang sesuai dengan kondisi dan karakteristik setiap daerah.

Berdasarkan pembahasan diatas mengenai kesulitan guru dalam mengembangkan indikator pembelajaran Kurikulum 2013 SDN 210 Bottopenno Kecamatan Majauleng Kabupaten Wajo sejalan dengan penelitian sebelumnya yang dilakukan oleh Haryati (2012) bahwa "kendala guru dalam mengembangkan indikator pembelajaran yaitukesulitan dalam menentukan jenis penilaian berupa kesulitan dalam penjabaran KD, kesulitan dalam membuat kisi-kisi instrumen penilaian, penyesuaian dengan karakteristik siswa yang belum bisa diakomodir dalam indikator pembelajaran". Begitu pula dengan penelitian yang dilakukan oleh Sri Hartini (2011) bahwa "dalam mengembangkan indikator, guru kesulitan dalam membedakan indikator dan tujuan, guru belum memahami KKO yang digunakan dalam mengembangkan indikator, guru belum memahami kaitan antara indikator dengan KD yang dikembangkan".

\section{KESIMPULAN}

Kesulitan yang dialami guru dalam mengembangkan indikator pembelajaran di SDN 210 Bottopenno Kecamatan Majauleng Kabupaten Wajo yaitu guru kesulitan dalam guru sulit dalam merumuskan atau menjabarkan kompetensi dasar (KD), guru kesulitan menentukan Kata Kerja Operasional (KKO), guru kesulitan dalam menentukan dan menyesuaikan kompetensi yang sesuai dengan karakteristik dan potensi, guru kesulitan dalam mengidentifikasi kemampuan 
yang dimiliki siswa, guru kesulitan dalam

dapat

sama

dalam menentukan kegiatan pembelajaran mengimplementasikan Kurikulum 2013 sesuai dengan indikator, guru juga dalam hal ini Rencana pelaksanaan kesulitan dalam menentukan jenis penilaian, dan guru mengatakan bahwa salah satu yang menjadi kendala dalam mengembangkan indikator pembelajaran Pembelajaran (RPP).

2) Guru/Wali Kelas, agar lebih meningkatkan kreatifitas dan inovasi dalam melaksanakan pembelajaran yang yaitu kurangnya pelatihan mengenai menyenangkan serta memotivasi peserta penyusunan RPP Kurikulum 2013 yang sesuai dengan kondisi dan karakteristik setiap daerah.

Berdasarkan kesimpulan hasil penelitian maka, saran disampaikan kepada: 1) Kepala SDN 210 Bottopenno diharapkan agar lebih meningkatkan lagi pendampingan serta mengupayakan peningkatan kualitas para guru baik dari segi perencanaan, pelaksanaan, hingga pengevaluasian pembelajaran pada Kurikulum 2013 yang berlaku, serta didik. Selain itu guru kelas diharapkan pula mendukung setiap perubahan Kurikulum yang ada dan meningkatkan kualitas diri melaui berbagai kegiatankegiatan pelatihan atau workshop Kurikulum 2013, 3) Peneliti lain, agar meneliti lebih lanjut mengenai pembuatan RPP dan Merumuskan indikator pembelajaran, dengan harapan dapat menemukan pemikiran yang inovatif guna meningkatkan mutu pendidikan dimasa depan.

\section{DAFTAR PUSTAKA}

Akhmad Sudrajat, 2011. Perbedaan Indikator Pencamapaian Kompetensi dan Tujuan Pembelajaran. Wordpress.

Badan Penelitian dan Pengembangan. 2013. Pengembangan bahan Ujiandan Penyusunan Kisi-Kisi Soal UjianUAMBN. Jakarta; Depdiknas

Badan Standar Nasional Pendidikan. 2010. Panduan Pengembangan Indikator. Direktorat Jenderal Manajemen Pendidikan Dasar dan Menengah Kementerian Pendidikan Nasional.

Depdiknas, D. P. 2003. Undang-Undang Nomor 20 Tahun 2003 tentang Sistem Pendidikan Nasional. Jakarta: Depdiknas, 33.

Ernawati, \& Safitri. 2018. Analisis Kesulitan Guru Dalam Merancang Rencana Pelaksanaan Pembelajaran Mata Pelajaran Fisika Berdasarkan Kurikulum 2013 Di Kota Banda Aceh. Jurnal Pendidikan Sains Indonesia, 5(2), 50-58..

Mulyasa. 2020. Perkembangan dan Implementasi Kurikulum. Bandung: PT. Remaja Posdakarya. 
Peraturan Presiden. 2017. tentang Penguatan Pendidikan Karakter.

Permendikbud. 2014. Pembelajaran pada Pendidikan Dasar dan Pendidikan Menengah.

Permendikbud. 2018. tentang Kurikulum Sekolah Dasar.

Prastowo, A. 2019. Analisis Pembelajaran Tematik Terpadu. Jakarta: Kencana.

Sri Haryati, 2013. Kendala Guru dalam Pengembangan Indikator Pencapaian Kompetensi Kajian Ketahanan Nasional pada Pembelajaran PPKn Sekolah Menengah Kejuruan. Semarang: Universitas Sebelas Maret Surakarta.

Sri Hartini, 2011. Pengembangan Indikator dalam Upaya Mencapai Kompetensi Dasar bahasa Indonesia di Sekolah Menengah Atas Kabupaten Karanganyar Jawa Tengah. Karanganyar; Disdikpora Kabupaten Karanganyar.

Sulistianingsih. 2013. Analisis Kemampuan Guru dalam Mengembangkan Indikator pembelajaran

Sugiyono. 2017. Metode Penelitian. Bandung: Alfabeta.

Warul, dkk. 2015. Metode Penelitian Kualitatif dan Grounded Theory, Aceh: FTK ArRaniry Press 